\title{
Changes in oxidative stress parameters in fish as response to direct uranium exposure
}

\author{
A. Buet, S. Barillet and V. Camilleri \\ Laboratory of Radioecology and Ecotoxicology, Institute for Radioprotection and Nuclear \\ Safety, DEI/SECRE/LRE, Cadarache Center, Bd. 186, BP. 3, St-Paul-lez-Durance, \\ France, e-mail: a.buet@free.fr
}

\begin{abstract}
The objectives of the present work were (1) to estimate the bioaccumulation of natural uranium (U) in a representative freshwater fish and (2) to assess the response of parameters involved in the defense against reactive oxygen species, in relation with the metal concentration and the exposure duration. Juvenile rainbow trout (Oncorhynchus mykiss) were exposed to a range of $\mathrm{U}$ concentrations in water $\left(20,100\right.$ and $500 \mu \mathrm{g} \mathrm{U} \mathrm{I}^{-1}$ ) during 10 days. The activity of antioxidant enzymes superoxide dismutases (SOD) and catalase were measured in trout liver. In parallel, $U$ analysis were performed in water and in trout gills. A significant accumulation of $U$ occurred in trout gills in relation with the concentrations of $U$ in water. SOD and catalase activities were both decreased by the exposure to $U$. U seemed to partly inhibit the antioxidant system of trout, indicating a potential enlarged sensitivity of exposed fish to oxidative damages.
\end{abstract}

\section{INTRODUCTION}

Uranium is among the heavy metals naturally present in aquatic ecosystems where its continued use in various anthropogenic activities may result in increased concentrations in water, sediment and aquatic organisms [1]. Because of its low specific activity, $\mathrm{U}$ toxicity is mainly chemical. Indeed, a growing body of evidences indicates that heavy metals chemical toxicity may be related with the stimulation of reactive oxygen species production in the course of redox reactions [2][3][4][5]. That results in numerous oxidative tissue damages affecting nuclear acids, proteins, lipids or carbohydrates. In this context, we proposed to estimate the accumulation of natural uranium in fish after short-term exposure to contaminated water (direct pathway exposure) and to assess the response of parameters involved in oxidative stress phenomenon. The rainbow trout (Oncorhynchus mykiss) was proposed as model organism as it is widespread in the world, its physiology is now well known and it is commonly used in ecotoxicological studies (i.e. standardized effluent lethal effects tests) due to its sensitivity to xenobiotics [6]. Three concentrations of $\mathrm{U}$ in water ranging from low to high-level concentration were tested and carefully chosen. The potential of $\mathrm{U}$ accumulation in trout tissue was assessed for each exposure dose at each exposure time. In parallel and owing to their key role in antioxidant defense against the toxic effects of reactive oxygen species, SOD and catalase enzymatic activities were measured in liver of rainbow trout. The results obtained in this experiment of short-term $U$ dose-effects relationships would provide useful information regarding more long-term effects of $U$ in aquatic organisms. 


\section{EXPERIMENTAL CONDITIONS AND MEASUREMENTS}

\subsection{Fish}

Juvenile rainbow trout with wet body weights and lengths of $5.8 \pm 1.3 \mathrm{~g}$ and $7.9 \pm 0.6 \mathrm{~cm}$ respectively $(n=172)$ were obtained from a hatchery (Hérault, France). They were allowed a one-month acclimation period to laboratory conditions prior to the experiments. They were kept in a storage tank with aerated fresh water $\left(10^{\circ} \mathrm{C}\right.$; artificial water in $\mathrm{mg} \mathrm{l}^{-1}: \mathrm{Ca}^{2+}=11.6 ; \mathrm{Mg}^{2+}=4.7 ; \mathrm{Na}^{+}=11.5 ; \mathrm{K}^{+}=6.3 ; \mathrm{Cl}^{-}=32.4 ; \mathrm{SO}^{2-}=9.6$; $\mathrm{NO}^{-}=31.0 ; \mathrm{CO}^{2-}=0.4 ; \mathrm{pH}=6.5$ ) renewed twice a week. Before and during the experiment, fish were fed daily on commercial food and light in the room followed a 12:12h photoperiod.

\subsection{Tanks and exposure}

The experimental system consisted of three experimental tanks (601) containing artificial water and receiving uranium-contaminated water from three $\mathrm{U}$ source tanks at a rate of $1.5 \mathrm{l} / \mathrm{h}$. That provided the complete renewal of the experimental tanks' water volume within $48 \mathrm{~h}$ and a constant ionic composition. An identical experimental tank was utilized as control unit, receiving water from a no contaminated source tank with the same flow rate. Each experimental unit contained 50 fish. All tanks temperature and $\mathrm{pH}$ were monitored daily.

U-source and experimental tanks were spiked with appropriated amount of uranyl nitrate solution

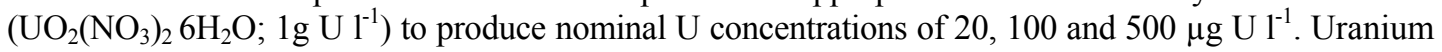
concentrations were maintained constant by the flow-through system and water samples were collected in each unit twice a day to monitor total uranium and main cations concentrations. Water samples were acidified by $2 \% \mathrm{HNO}_{3}$ and maintained in darkness at $4{ }^{\circ} \mathrm{C}$ prior to ICP-AES analyses.

Trout were introduced in the experimental tanks when $\mathrm{U}$ concentrations in the system were stable. Forty

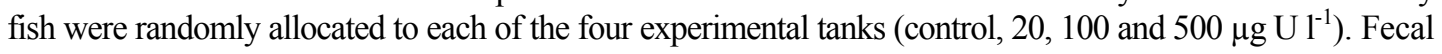
materials and excess food accumulated on the bottom of the tanks were removed daily.

\subsection{Sampling}

Ten fish were collected in each of the four tanks (control and experimental ones) after 0.25, 1, 5 and 10 days. They were sacrificed via an incision behind the head and immediately weighed and measured. Liver and gills were carefully excised, measured and kept at $-80^{\circ} \mathrm{C}$ with body residues before uranium or biochemical analyses.

\subsection{Uranium analysis}

Uranium accumulation was determined in gills of trout. Gills were digested in tubes containing $3 \mathrm{ml}$ of nitric acid heated at $95^{\circ} \mathrm{C}$ for $3 \mathrm{~h}$ and at $105^{\circ} \mathrm{C}$ for $1 \mathrm{~h}$. Tubes were cooled and $10 \mathrm{ml}$ of acidified ( $2 \%$ nitric acid) ultra-pure water was added for ICP-AES analysis. The detection limit under the presented conditions was determined to be $5 \mu \mathrm{g} \mathrm{U} / \mathrm{l}$. No certified biological material was available for monitoring the accuracy of uranium analysis. Then, mineralized no contaminated gills samples were spiked with known concentration of uranium and analyzed as internal reference standards.

\subsection{Kinetic enzyme assays}

SOD and catalase activities were measured in liver. Livers were homogenized in ice-cold Tris buffer $(50 \mathrm{mM}, \mathrm{pH} 7.4$ and $1 \mathrm{mM}, \mathrm{pH} 8.0$ respectively) using a Potter-type homogenizer (Eurostar digital, IKA Labortechnik). Liver homogenates were centrifuged at 2,000 $\mathrm{x}$ g for $10 \mathrm{~min}$ at $4^{\circ} \mathrm{C}$ (Beckman 
Coulter, J-301, USA) and the resulting supernatants were centrifuged at $12,000 \mathrm{x} \mathrm{g}$ for $15 \min \left(4^{\circ} \mathrm{C}\right)$. Antioxidant activities were measured on the resulting post-mitochondrial fractions. The total SOD activity was determined after hemoglobin precipitation and extraction in ethanol/dichloromethane $(2 / 1 ; \mathrm{v} / \mathrm{v})$. The inhibitory action of SOD on epinephrine oxidation by superoxide anion was followed at $480 \mathrm{~nm}$ according to the method of Misra and Fridovich [7] slightly modified by H. Roche [8]. The catalase activity was evaluated using the hydrogen peroxide breakdown method [9]. Each activity was measured at $25^{\circ} \mathrm{C}$ in triplicates for catalase and in four replicates for SOD. Protein content was determined by the Bradford dye-binding procedure using serum albumin bovine as standard [10].

All chemicals and reagents were purchased from Sigma-Aldrich (Saint-Quentin, France) except nitric acid obtained from Merks, USA.

\subsection{Statistical analysis}

Tests for all data normality and homogeneity of variance were carried out. Then, ANOVA or Kruskal-Wallis methods were performed in order to use the post-hoc LSD-Fisher or Nemenyi multiple comparisons tests with $\alpha=0.05$. All statistical calculations were conducted on the STATISTICA 6 . software.

\section{RESULTS AND DISCUSSION}

\section{1 $\mathrm{U}$ accumulation in trout gills}

The concentrations of uranium in gills of trout are presented in Fig. 1. U concentrations in control fish were lower than the detection limit. The concentrations of $\mathrm{U}$ in gills from the lowest exposed group $\left(20 \mu \mathrm{g} \mathrm{U}^{-1}\right)$ were not significantly greater than control except after 5 days of exposure $\left(0.45 \mu \mathrm{g} \mathrm{U} \mathrm{L}^{-1}, P=0.011\right)$. The results obtained for the two other concentration groups $\left(100 \mu \mathrm{g} \mathrm{U} \mathrm{l^{-1 }}\right.$ and $\left.500 \mu \mathrm{g} \mathrm{U}^{-1}\right)$ showed a dose dependence of the accumulation of $U$ in trout gills. $U$ accumulation in gills increased with increasing $U$ concentration in water at each exposure time $(P<0.001)$. Indeed, low accumulation of $U$ occurred in gills from the medium exposed group $\left(100 \mu \mathrm{g} \mathrm{U}^{-1}\right)$. The concentrations were below $1 \mu \mathrm{g} \mathrm{g}^{-1}$ fw and almost constant but significantly higher than control at the exposure times 0.25 day $(P<0.001), 1$ day $(P<0.001), 5$ days $(P=0.008)$ and 10 days $(P=0.002)$. The highest significant concentrations were achieved in gills from the high exposed fish $\left(500 \mu \mathrm{g} \mathrm{U} \mathrm{l}{ }^{-1}\right.$ in water) after 1 and 10 days with $2.0 \mu \mathrm{g} \mathrm{U} \mathrm{g}^{-1} \mathrm{fw}$ and $2.9 \mu \mathrm{g} \mathrm{U} \mathrm{g}^{-1} \mathrm{fw}$ respectively $(P<0.001)$. The concentrations of $\mathrm{U}$ in this group were also significantly greater than those observed in the low exposed group after 0.25 day $(P=0.039), 1$ day $(P=0.013)$ and 5 days $(P=0.002)$. Cooley and Klaverkamp [11] studying the dose dependence of $U$ accumulation by the trophic way found that only the highest exposure concentration of $\mathrm{U}$ in commercial diet (10 $\left.000 \mu \mathrm{g} \mathrm{U} \mathrm{g}^{-1}\right)$ led to significant accumulation in gills of whitefish [2]. In our study, the highest accumulation was obtained after 10 days of exposure in the $500 \mu \mathrm{g} \mathrm{U} \mathrm{l^{-1 }}$ group $\left(2.9 \mu \mathrm{g} \mathrm{U} \mathrm{g}^{-1}\right)$. Despite the relatively low observed concentrations of $\mathrm{U}$, gills are recognized to play a key role in the uptake of metals in fish exposed by direct pathway. They represent the first step of the absorption of soluble metal fractions in organisms prior to their distribution throughout the whole body and their potential deleterious effects in target organs. 

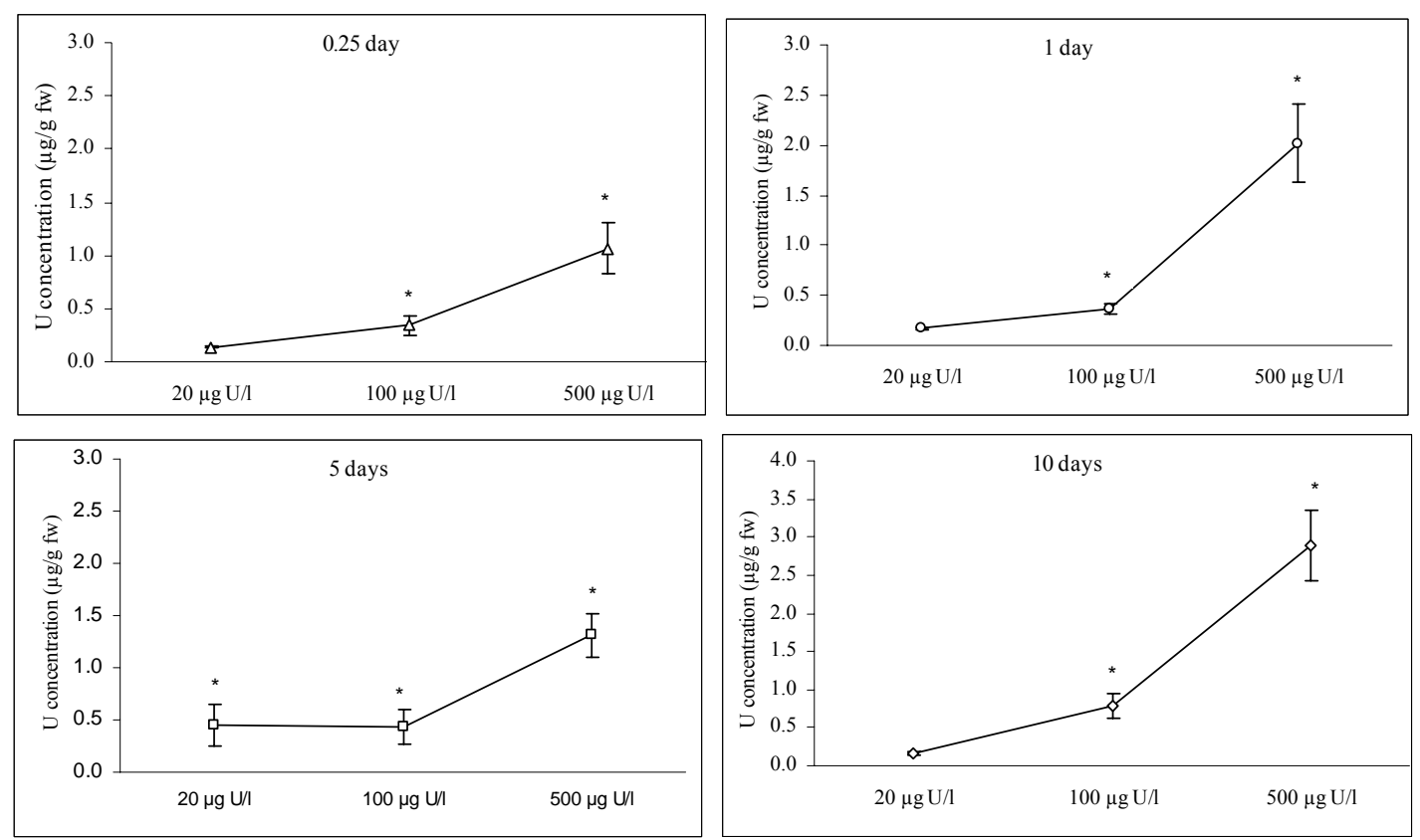

Figure 1. Concentrations of $U$ in trout gills $\left(\mu \mathrm{g} \mathrm{g}^{-1} \mathrm{fw}\right)$. Data are expressed as mean (ten fish) \pm S.E.M. Asterisks denote means significantly different from control $(P<0.05)$.

\subsection{Antioxidant markers}

In response to uranium exposure, significant variations were observed in hepatic total SOD and catalase activities (Fig. 2). Antioxidant activities were generally lower in uranium-exposed trout than in control with the exception of SOD after 1 day. Moreover, the decrease of enzymatic response was both time and dose-dependent $(P<0.001$ and $P=0.002$ respectively). The reduction of SOD activity relative to control ranged between $20 \%$ for the $20 \mu \mathrm{g} \mathrm{U}^{-1}$ group $(P=0.02)$ to $46 \%$ for the $500 \mu \mathrm{g} \mathrm{U}^{-1}$ group $(\mathrm{P}<0.001)$ after 0.25 day. It was also significant in trout exposed during 5 days to 20 and $100 \mu \mathrm{g} \mathrm{U}^{-1}$ in water (27\% and $36 \%$ of decrease respectively; $P=0.04$ and 0.008 ). A similar tendency was observed in catalase activity after 5 days of exposure. A reduction of $32 \%$ occurred in the $20 \mu \mathrm{g} \mathrm{U}^{-1}$ group

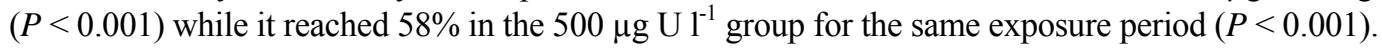

A decrease of antioxidant enzyme activities was also observed in Brachydanio rerio exposed to $U$ in vitro and in vivo [5]. Both exposures induced a lower catalase activity with a decrease ranging between $15 \%$ to $34 \%$ in relation with the dose ( 0.4 to $2.5 \mathrm{~g} \mathrm{U} \mathrm{l}^{-1}$ in vitro and 75 to $750 \mu \mathrm{g} \mathrm{U} \mathrm{l}{ }^{-1}$ in vivo). Other metals seem to have the same enzyme-inactivating power as uranium. Roméo et al. demonstrated a significant reduction of catalase activity as a function of cadmium concentration in the kidney of sea bass (Dicentrachus labrax) following in vivo injection of the metal [12]. Moreover, copper and zinc ions, known as potent antioxidant activators, caused a general and unexpected decrease of SOD and catalase activities in sea bass erythrocytes exposed in vitro [2]. Our results did not allow to conclude on the precise mechanism involved in $U$ effects but the inhibition of antioxidant activities by heavy metals exposure has been interpreted as the consequence of possible excessive production of free radicals (for example an inhibition of SOD by its own product, the hydrogen peroxide) or by a covalent attachments of the metals with sulfhydryl groups of proteins [4][5][13]. 

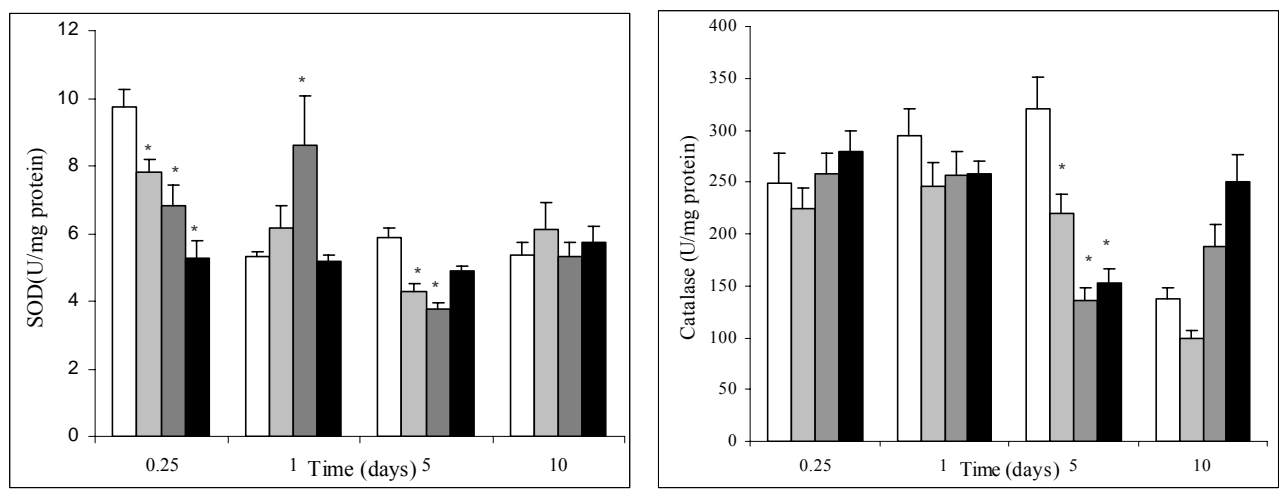

Figure 2. SOD and catalase activities ( $\mathrm{U} \mathrm{min} \mathrm{mg}^{-1}$ protein) of trout exposed to uncontaminated and $\mathrm{U}$ contaminated water during 0.25, 1, 5 and 10 days. $\square$ control, $\square 20 \mu \mathrm{g} \mathrm{U} \mathrm{l}^{-1}, \square 100 \mu \mathrm{g} \mathrm{U} \mathrm{l}^{-1}$ and $\mathbf{\square} 50 \mu \mathrm{g} \mathrm{U} \mathrm{l}^{-1}$. Data are expressed as mean (ten replicates) \pm S.E.M. Asterisks denote means significantly different from control $(P<0.05)$.

\section{CONCLUSION}

These results demonstrated the dose-dependent accumulation of $U$ waterborne in gills of juvenile rainbow trout following short-term exposure. Gills appeared as relevant site of soluble uranium fractions uptake and transfer in such direct pathway. Direct exposure of fish to natural uranium did not induce catalase and SOD activities that are involved in the protection of organisms against reactive oxygen species. Contrary to what was observed for some other heavy metals in other conditions, the response of both enzymes was significantly reduced by $U$ exposure suggesting a possible deterioration of the protective defense system of fish. The potential impair of antioxidant defenses by $U$ should make cells and whole organism more susceptible to oxidative attacks and further deleterious effects.

\section{Acknowledgments}

This work was supported by the ENVIRHOM research program funded by the Institute of Radioprotection and Nuclear Safety.

\section{References}

[1] Poston T.M., Bull. Environm. Contam. Toxicol. 28 (1982) 682-690.

[2] Cooley H.M. and Klaverkamp J.F., Aquat. Toxicol 48 (2000) 477-494.

[3] Roche H. and Boge G., Toxic in Vitro 7, 5, (1993) 623-629.

[4] Dallinger R. Prosi F., Segner H. and Back H., Oecologia 73 (1987) 91-98.

[5] Ercal N., Gurer-Orhan H. and Aykin-Burns N., Cur. Top. Medicinal Chem. 1 (2001) 529-539.

[6] Labrot F., Ribera D., Saint Denis M. and Narbonne J.F., Biomarkers 1 (1996) 21-28.

[7] Manzl C., Ebner H., Köck G., Dallinger R. and Krumschnabel G., Toxicol. Appl. Pharmacol., 191 (2003) 235-244.

[8] Misra H.P. and Fridovich I., J Biol Chem 247 (1972) 3170-3175.

[9] Buet A., Impact biologique des hydrocarbures aromatiques polycycliques (HAP) chez l'anguille européenne. Définition et validation de biomarqueurs in situ. Thesis Paris, n¹12052 (2002) 203 pp.

[10] Beers R.F. and Sizer I.W., J Biol Chem 195 (1952) 133-140.

[11] Bradford M.M., Anal Biochem 72 (1976) 248-254.

[12] Romeo M., Bennani N., Gnassia-Barelli M., Lafaurie M. and Girard J.P., Aquat. Toxicol. 48 (2000) 185-194.

[13] Lackner R. Fish ecotoxicologie (Braunbeck T., Hinton D.E., Streit B., Bale, 1998) pp 203-224. 